\title{
Cooperatives in IT sector: theoretical and practical aspects
}

\author{
V. Honcharenko ${ }^{1}$, A. Panteleimonenko ${ }^{2}$, A. Pozhar $^{3}$, V. Stetsenko ${ }^{4}$ \\ ${ }^{1}$ School of International Economic Relations and Travel Business, V.N. Karazin Kharkiv National University, Kharkiv, Ukraine \\ ${ }^{2}$ Department of Tourist and Hotel Business, Poltava University of Economics and Trade, Poltava, Ukraine \\ ${ }^{3}$ Department of International Economics, Poltava University of Economics and Trade, Poltava, Ukraine \\ ${ }^{4}$ Department of HR Management, Labor Economics and Economic Theory, Poltava University of Economics and Trade, Poltava, \\ Ukraine
}

\begin{abstract}
Article Info
Received Dec 22, 2018

\section{Keyword: \\ Cooperatives \\ IT-cooperatives \\ Co-operative models \\ Information Technologies}

ABSTRACT

Information technologies are developing rapidly. The number of people envolved in IT sector is also growing fast. Users, freelancers, software developers, IT companies create various formal and non-formal interest groups: community, hackathons, co-workings, hackerspaces, IT-clusters, and others. IT-cooperative is one of these new, very promising, but yet littleknown forms. The article reveals the features of cooperative as a unique form of business based on solidarity and ethical principles. The article shows the reasons of cooperatives emergence, their types and varieties, features and extent of development in the world and in separate sectors of economy of different countries. The basic cooperative principles, which make coops unique and distinguish them from other forms of business activity, are analyzed. The experience and activity of individual IT-cooperatives in different countries are generalized. The emphasis is made on the benefits cooperative business model can provide the IT specialists with. Several possible promising models of IT-cooperatives are developed. There is not information about existence of such models yet, but they can be created potentially.
\end{abstract}

\section{Corresponding Author:}

Artem Pozhar, Department of International Economics, Poltava University of Economics and Trade, Kovalya str., 3, Poltava, Ukraine, 36039

Email: art.pozhar@gmail.com

\section{Introduction}

Information technology is rapidly increasing its role in both economy and society. It is impossible to imagine our life without IT. According to Gartner Inc., world total IT expenditure was predicted to total \$ 3.7 trillion in 2018, growth of 6.2 percent from 2017 and will grow rapidly in subsequent years [22]. The number of people engaged in this sector is growing rapidly. The first group is users, the second one is developers of software, the third one is owners of IT companies. Thus, people start joining different formalized and nonformalized interest groups, such as: community, hackathon, co-working, hackerspace, networks, IT-cluster, and others. IT-cooperatives became one of these new forms of association. The search on the global computer network allowed us to find some websites of such cooperatives in different countries. However, looking for information in scientific databases on IT-cooperatives has shown that this is a rather new and almost not researched topic for scientists. There may be several explanations for this. First, such cooperatives are still relatively small, so they have not attracted much attention from the scientists. Second, various types of 
cooperatives and cooperative movement in general is researched by a small number of scientists in the world. Nevertheless, the issues of history and theory of cooperative movement at the present stage are studied in many countries of the world as a reference to the peculiarities of this or that type of cooperative: consumers' coops [6], [18], [9] or, for example, credit coops [29]. An attempt to consider economic and organizational nature of coops throught identifying their place and role among the rest of the economic institutions is an important direction of researching theoretical issues of cooperatives' development. Thus, Chaddad [4] defines a cooperative nature as a hybrid, that is, a combination of market-like attributes with hierarchy-like mechanisms. Other scientists are trying to consider and compare the peculiarities of cooperatives' development in the regional, historical and geopolitical terms, paying attention to the influence of general civilizational development of various countries and regions on cooperative movement [5], [32]. At the same time, the economic nature and economic effect of cooperative activities cannot be considered separately from their social function. Therefore, analysis of cooperative movement sometimes turns into a study of a broader concept of the "social economy", that is, such a system of constructing socio-economic relations which maximally takes into account the interests of majority of the population, based on the ideas of self- and mutual aid, non-profit, strong civil society [26], [1]. Recently, the attention of cooperative movement researchers was attracted by so-called workers' cooperatives, the associations of certain professions representatives, created in order to increase the efficiency of their own activity. The nature of workers' cooperatives is studied by Majee [21], the features of their functioning are described by Lima [20], Burdin [3], Sapovadia [27], Sengupta [28], Babenko [2]. However, the problems of IT-cooperatives development have not been reflected yet. This is a relatively new form of cooperation inside IT sector which needs generalizing, theoretical interpretation and elaborating possible models for the further development of IT-cooperatives. Our article is devoted to considering these issues.

\section{Material and methods}

It was mentioned above that we have not found enough generalized theoretical and statistical information regarding the development of cooperatives in IT sector. In the process of research, we relied on information from existing web-sites of specific cooperatives and available information sources on the activities of cooperatives in other sectors. The use of historical method and method of analogy made it possible to conclude that IT-cooperatives have unique nature, cooperative business model in IT sector is very promising, showing the trends of further development. The method of generalization allowed us to define the most common types of IT-cooperatives' activities in different countries, identify general patterns of their development in modern conditions. Logical method allowed us elaborate several possible and perspective models of IT-cooperatives. There is not information about existence of such models yet, but they can be created potentially. In the process of research we also used universal methods of scientific knowledge: analysis and synthesis, induction and deduction, modeling.

\section{Theory}

Cooperatives present a unique phenomenon in the global economy. They belong to the sector of social economy, and they play an extremely important role for many people in different countries. That is why the UN announced 2012 the Year of Cooperatives. In 2016, UNESCO inscribed "Idea and practice of organizing shared interests in cooperatives" on the Representative List of the Intangible Cultural Heritage of Humanity [31]. There is not all-embracing international statistics on the number and key performance indicators of all cooperatives. According to the United Nation's Secretariat in 2014 there were more than 2.6 Million Cooperatives with over 1 Billion members/clients, 12.6 Million Employees. 20 Trillion USD in Cooperative Assets create 3 trillion USD in Annual Revenue. But this is not complete data. It relates to only 145 countries studied. For example, there is no information on the cooperatives in China [8]. According to ICA which is worldwide association of national and regional cooperative associations from more than 100 countries - at least $12 \%$ of all the people are members of at least one of 3 million cooperatives worldwide. Cooperatives create jobs for $10 \%$ of all population employed, and 300 top cooperatives or cooperative groups generate 2.1 Trillion USD in turnover [16]. 


\subsection{Population membership in cooperatives}

Our research of cooperatives development in certain countries indicates that there is over 9.3 million people who are members of cooperatives in Argentina, which is $23 \%$ of all the economically active population of this country. Almost one third of Bolivia population enjoys the services of cooperatives. 7.6 million Brazilians are members of nearly 7,600 cooperatives of various types. In Canada, four in ten Canadians take part in activity of at least one cooperative. At the same time, about 70\% of Canadian province Quebec population, and 56\% people of province Saskatchewan are participating in cooperatives. In Finland, $62 \%$ of all households joined the cooperative network S-Group. In France, 23 million citizens or 38\% of population participate in one or more cooperatives. At the same time, $75 \%$ of French farmers take part in at least one cooperative, and every third one is a participant of a cooperative bank. 20 million Germans take part in cooperatives, and that is every fourth resident. In Japan, every third resident is cooperative member as well as $90 \%$ of local farmers. In Norway, with 4.8 million population, 2 million people take part in cooperative organizations. At the same time, many people are simultaneously members of several cooperatives of different types [24]. 50\% of Singapore population (over 1.6 million) participate in cooperatives. There are more than 29,000 cooperatives in the US. It means that every fourth American citizen is a member of a cooperative. At the same time, it should be noted that not only people (as individuals) are members of different types of cooperatives, but also small and micro businesses created by them.

\subsection{The role of cooperatives in the economy}

Cooperatives have managed to take a prominent place in various sectors of economy. For example, the share of Belgium cooperative drugstores is $19.5 \%$ of the national market. In Cyprus, $30 \%$ of banking services and $35 \%$ of agricultural products sales are carried out through cooperative organizations. In the Netherlands, cooperatives create $18 \%$ of GDP. In Denmark, consumer cooperatives make more than $36 \%$ of retail sales. In Finland, cooperatives create $14 \%$ of GDP, in particular, Cooperative Pellervo group is selling $74 \%$ of all processed meat, $96 \%$ of milk products, and $50 \%$ of eggs. In France, cooperatives control $60 \%$ of banking market, $40 \%$ of agricultural prooducts and food market, $25 \%$ of retail trade and create $18 \%$ of GDP. In Korea, fishing cooperatives control $71 \%$ of the market. In Kenya, cooperatives create $45 \%$ of GDP. They control $70 \%$ of coffee market, $76 \%$ of milk market, and $95 \%$ of cotton market. Cooperatives of New Zealand create $20 \%$ of GDP, control $70 \%$ of meat and meat products market, $95 \%$ of dairy products market and their exports. In Norway, 130 consumer cooperatives control 24\% of consumer market, while 71 housing cooperatives control $15 \%$ of the total housing stock in the country. The biggest travel agency of the UK is cooperative. In the United States, more than 900 rural electricity cooperatives sell electricity to over 42 million members in 47 states. The presented data show not only the popularity of cooperatives among the population, but also high competitiveness of cooperatives in modern conditions of the globalized world.

\subsection{Reasons for cooperatives emergence}

Such scale of cooperatives development in the world economy is a consequence of their particular socioeconomic model. Cooperatives have unique "cooperative philosophy" at the heart of them. Modern cooperatives are evolutionary forms of the first cooperatives that began to appear more than 150 years ago in the middle of the nineteenth century. In those difficult times, people began to join into cooperatives to supply themselves with goods and services as well as jobs on more favorable terms than market was offering. The idea of improving people's level of life on the basis of association and economic mutual assistance on a democratic principle was different from the traditional at that time forms of capitalistic business which was orienting on profit maximizing. One of the first ideologists of cooperative movement, German cooperative leader F.W. Raiffeisen said - "Cooperatives are not a means of wealth, but a way to fight poverty" [13]. Cooperative business model was created to provide its members-owners with necessary goods and services at prime cost. It significantly differed from the capitalistic forms of business, aimed at obtaining maximum profit from their customer. Membership in cooperatives made it possible for people to avoid consuming services of various trading and other intermediaries with their aspirations for high profits. People became able to spend less through perchasing from their own cooperatives (as they were not only clients but also equal co-owners). They could also sell the production of their private farms through their cooperatives for better prices. 
Workers' cooperative is a separate form of cooperative. They are created by people to supply themselves with jobs and produce their goods and services together.

\subsection{Conditions for cooperatives development}

It should be noted that development of cooperatives in each country has its own peculiarities due to national legislations. That is why different countries have different models of cooperatives. In the countries with favorable cooperative legislation (the USA, Canada, most of European countries, Japan etc.) cooperatives develop on the basis of classical "cooperative philosophy", albeit with some differences (thus, credit unions in the United States provide services exclusively to their members and have tax benefits while cooperative banks in Europe provide services not only for the members and do not have tax privileges). In such countries, cooperatives often receive a special legal status of non-profit or not-for-profit organizations, and their activity is regulated by special (cooperative) legislation [14]. In the countries with unfavorable legislation (the Middle East and Africa), cooperatives are developing problematicaly or not developing at all. In communist countries (the USSR, Cuba, and Eastern Europe countries), the classical model of cooperative was incompatible with the command and administrative system. That is why the Soviet model of cooperative was deformed. Cooperative in those countries meant an organization that did not really meet the cooperative philosophy and classical understanding the essence of a cooperative. In fact, it was pseudo-cooperative.

\subsection{General definition of a cooperative at the international level}

For a long time there was no single definition of the concept "cooperative" and governments of different countries treated cooperatives differently. That is why, the International Labor Organization (ILO) adopted the Co-operatives (Developing Countries) Recommendation, 1966 (No. 127), "The Role of Co-operatives in the Economic and Social Development of Developing Countries", which indicated the need for state support for cooperatives, the protection of the name "co-operative", which is "... an association of persons who voluntarily joined together to achieve a common end through the formation of a democratically controlled organization, making equitable contributions to the required capital and accepting a fair share of the risks and benefits of the company in which the members actively participate" [7]. This recommendation contributed to the unification of legislation for cooperatives in numerous countries and the active development of cooperatives. Later, in 2002, the ILO slightly corrected the definition of "cooperative" by establishing that it was a "autonomous association of persons united voluntarily to meet their common economic, social and cultural needs and aspirations through a jointly owned and democratically controlled enterprise." [25]. At that, ILO documents pointed out that cooperatives distribute the following values: self-aid, self-responsibility, democracy, equal rights, equity and solidarity; together with moral values of veracity, objectiveness, social responsibility and concening for others. In addition, it was stated that cooperatives function basing on the complex of principles formulated by ICA.

\subsection{Types of cooperatives}

Currently, there is a large variety of cooperatives. They propose a lot of services to their members [12]. Consumer cooperatives provide their members with high-quality goods at lower prices. Financial and credit cooperatives (credit unions, cooperative banks, insurance cooperatives etc.) provide their members with financial services. Medical cooperatives provide their members with medical services. Selling and processing cooperatives help farmers to sell their products, including transactions at the world markets. Co-operative fuel stations provide their members with cheaper fuel and automobile oil. Energy cooperatives provide electricity, usually from renewable sources like wind or sun. Tourist cooperatives offer their members affordable travel services. Lease cooperatives provide their members with leasing services. Housing cooperatives help to provide their members with housing and communal services. It is difficult to list all the types and kinds of cooperatives in the world. They are created mainly in those sectors of economic activity, where people have a great need for certain goods, services or jobs, as well as desire to save money and avoid various commercial intermediaries [23]. 


\subsection{Principles of cooperatives acitivity}

Despite the large variety of types and sectors of cooperatives activity, all coops have the same socio-economic nature. They are characterized by common features, based on "cooperative philosophy" and ideas of the first cooperative leaders. These features are called "international cooperative principles". They were formulated on the basis of cooperative practice. The International Co-operative Alliance was the first to formulate them [12]. Cooperative activities are now recognized by the governments of most countries, the UN, ILO, UNESCO, FAO and other international organizations. ICA cooperative principles were formulated due to the practice of various types cooperatives in many countries [11]. They are universal and characterize the features of a cooperative as a unique form of business only in general. In cooperative practice and national legislations, these principles become more detailed. We tried to group them into 3 interconnected blocks: economic principles, organizational principles and social principles (Table 1)

Table 1. Principles of cooperative organizations [10], [12]

\begin{tabular}{|c|c|c|}
\hline Economic principles & Organizational principles & Social principles \\
\hline $\begin{array}{l}\text { The cooperative operates to meet } \\
\text { the common economic needs of its } \\
\text { members on a non-profit basis (at } \\
\text { prime cost) }\end{array}$ & $\begin{array}{c}\text { Membership in the cooperative is } \\
\text { voluntary and personal (can not be } \\
\text { passed on to other persons and } \\
\text { inherited) }\end{array}$ & $\begin{array}{l}\text { Creation of economic self-help } \\
\text { system on the basis of mutual } \\
\text { assistance }\end{array}$ \\
\hline $\begin{array}{l}\text { Members of cooperative are } \\
\text { owners and customers of this } \\
\text { cooperative at the same time* }\end{array}$ & $\begin{array}{l}\text { Membership in a cooperative is } \\
\text { open (membership is potentially } \\
\text { available) }\end{array}$ & $\begin{array}{l}\text { Socially homogeneous } \\
\text { membership in cooperative on the } \\
\text { basis of common economic and } \\
\text { social interests }\end{array}$ \\
\hline $\begin{array}{l}\text { The cooperative provides services } \\
\text { to its members in order to reduce } \\
\text { costs and / or increase their } \\
\text { personal income }\end{array}$ & $\begin{array}{l}\text { Democratic governance } \\
\text { and control in cooperative } \\
\text { on the principle "one member - } \\
\text { one vote", regardless of the } \\
\text { amount of money invested }\end{array}$ & $\begin{array}{c}\text { Education of members and } \\
\text { employees, teaching people } \\
\text { democratic principles of } \\
\text { cooperative movement }\end{array}$ \\
\hline $\begin{array}{c}\text { Just and proportionate financing } \\
\text { the cooperative activities by its } \\
\text { members }\end{array}$ & $\begin{array}{c}\text { Transparency of the cooperative } \\
\text { activity and equal rights for the } \\
\text { members }\end{array}$ & $\begin{array}{c}\text { Altruism of the members, which is } \\
\text { based on solidarity of social } \\
\text { groups }\end{array}$ \\
\hline $\begin{array}{c}\text { Capital of cooperative is formed } \\
\text { by its members and consists of } \\
\text { shares and indivisible (collectively } \\
\text { owned) part }\end{array}$ & $\begin{array}{l}\text { The activities of the elected bodies } \\
\text { of management and control are } \\
\text { carried out on a voluntary basis. } \\
\text { Only hired employees are paid }\end{array}$ & $\begin{array}{l}\text { Cooperation with other } \\
\text { cooperatives in order to strengthen } \\
\text { and develop a cooperative system } \\
\text { of mutual assistance }\end{array}$ \\
\hline $\begin{array}{l}\text { The remuneration of the invested } \\
\text { capital (per share) is limited }\end{array}$ & $\begin{array}{l}\text { The members are responsible for } \\
\text { the work and development of their } \\
\text { cooperative }\end{array}$ & $\begin{array}{l}\text { Care about the community (to } \\
\text { which the coop members relate) }\end{array}$ \\
\hline
\end{tabular}

The principles in the table characterize cooperative as a unique form of business, which corresponds to cooperative idea and philosophy of cooperative movement. Cooperative differs from classical business, focused on maximizing profits.

\section{Results and Discussion}

\subsection{The suggested definition and classification of cooperatives}

We propose the following definition based on analysis of socio-economic nature of cooperatives as unique form of people association:

Cooperative is a very unique form of people association. It is an open democratic association of individuals created for the purpose of self-supplying with the necessary goods, services or jobs, which carries out economic activity on behalf and for the benefit of its members who are its equal owners and customers.

All the cooperatives, regardless of their sector of activity, can be divided into 2 large groups:

1) customers' cooperatives - setisfy the needs of their members with goods and (or) services; 
2) workers' cooperatives - provide their members with jobs (collective business).

1) Customers' cooperative is open democratic association of people created for the purpose of self-supplying with necessary goods and / or services, which carries out economic activity due to cooperative principles on behalf and for the benefit of its members, who are equal owners and customers. Such cooperatives are managed by and belong to the customers, who have equal rights.

2) Workers' cooperative is open democratic association of people created for the purpose of their selfsupplying with jobs that carries out economic activity basing on cooperative principles on behalf and for the benefit of its members, who are equal owners and workers. Such cooperatives are managed by and belong to the workers, who have equal rights.

These two groups of cooperatives fundamentally differ from each other by motivation: for the founders when starting, as well as for the new members when joining the cooperative. The motivation to participate in customers' cooperatives is striving to get goods and / or services at better conditions. The motivation to participate in workers' cooperative is striving to get better job conditions.

\subsection{General characteristics of the researched IT-cooperatives}

The analysis of raw data from IT-cooperatives' websites in different countries showed that $97 \%$ of them could be classified as workers' cooperatives. The remaining 3\% of such cooperatives could not be classified like that because of lack of necessary information. IT-cooperatives provide a lot of services. The main services and features of the researched IT-cooperatives in the US and UK are grouped in tables 2-3.

Table 2. Services of some IT-cooperatives in the UK

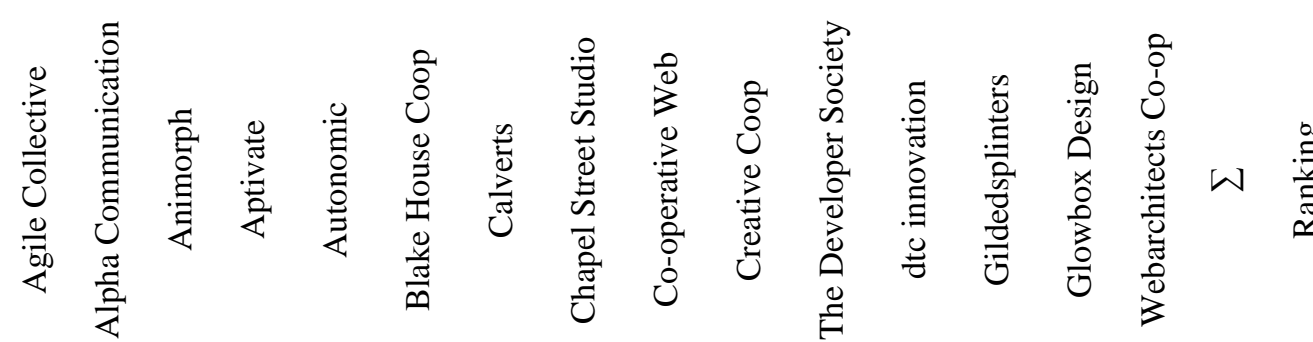

\begin{tabular}{|c|c|c|c|c|c|c|c|c|c|c|c|c|c|c|c|c|c|}
\hline Animation & & + & + & & & + & & + & & & + & & & & & 5 & 6 \\
\hline Art work & & + & + & & & & + & + & & + & + & & & + & & 7 & 4 \\
\hline $\begin{array}{l}\text { Branding and } \\
\text { identity }\end{array}$ & + & + & + & & & & + & + & & + & + & & + & + & & 9 & 2 \\
\hline Consultancy & + & + & & + & & + & + & + & + & & & & + & & + & 9 & 2 \\
\hline Development & + & & + & + & + & & & + & + & & + & + & & + & + & 10 & 1 \\
\hline $\begin{array}{l}\text { Graphic } \\
\text { design }\end{array}$ & + & + & + & & & & + & + & & & + & & & + & & 7 & 4 \\
\hline Hosting & & & & + & + & & & + & + & + & + & & & & & 6 & 5 \\
\hline $\begin{array}{l}\text { Idea } \\
\text { generation }\end{array}$ & + & & + & & & & + & + & + & & + & + & + & & & 8 & 3 \\
\hline Illustration & & + & & & & & & + & & + & + & & & + & & 5 & 6 \\
\hline Logo design & + & + & & & & & + & + & & + & & & & + & & 6 & 5 \\
\hline Mailing & & & & & & & + & & & & & & & & & 1 & 10 \\
\hline Marketing & & + & & & & + & & + & & + & & & + & & & 5 & 6 \\
\hline Mentoring & & + & & & & & & & + & + & & + & + & & & 5 & 6 \\
\hline Motion Graph & & + & + & & & + & & + & & & & & & & & 4 & 7 \\
\hline Printing & & + & & & & & + & + & & + & + & & & & & 5 & 6 \\
\hline SEO & + & & & & + & & & & & + & & & & & & 3 & 8 \\
\hline Strategy & & & & + & & & & & & & + & & & & & 2 & 9 \\
\hline Sysadmin & + & & & & + & & & & & & & & & & & 2 & 9 \\
\hline Web Design & + & + & & + & + & & + & + & & + & + & & & + & & 9 & 2 \\
\hline
\end{tabular}


Table 3. Services of some IT-cooperatives in the USA

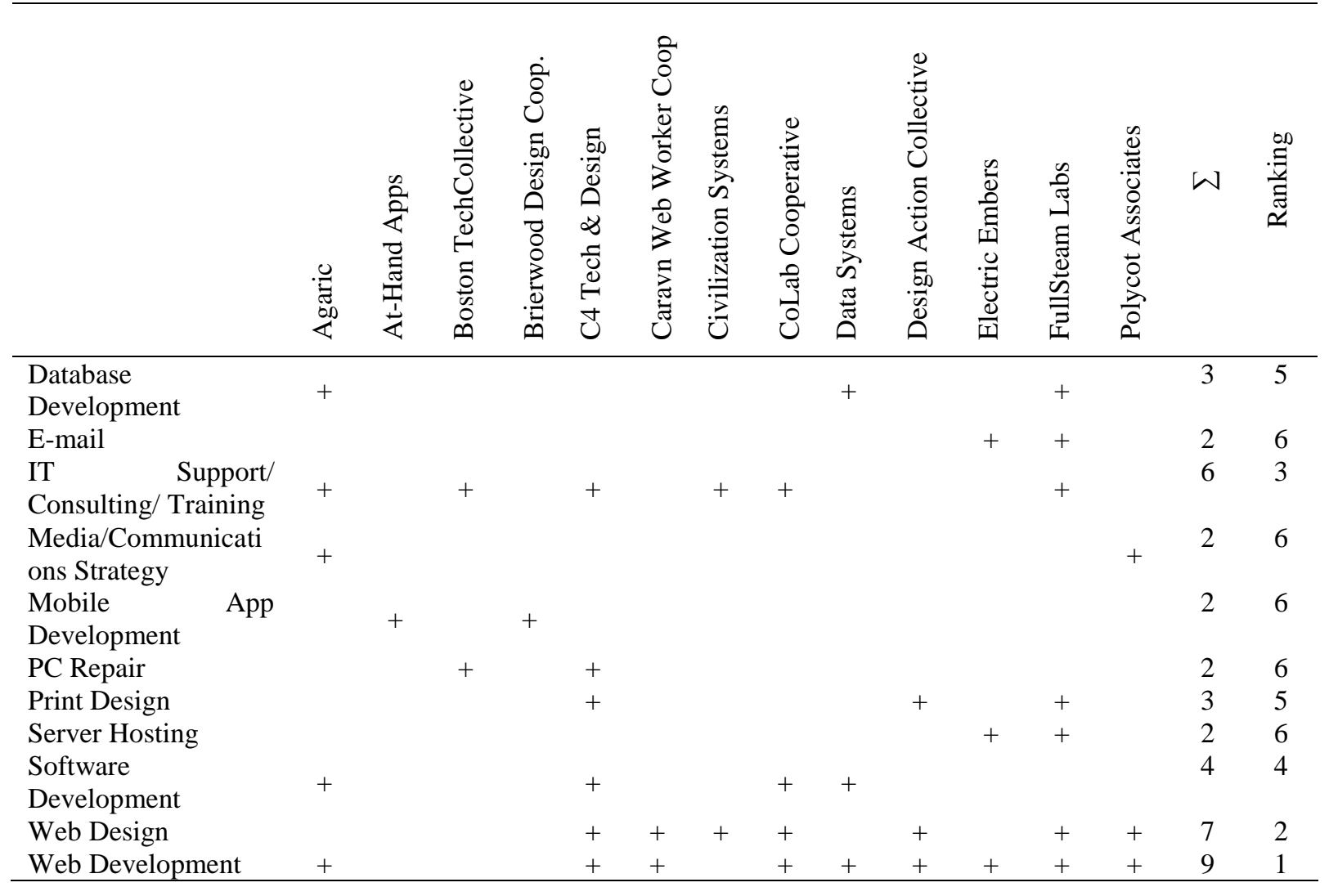

\subsection{Motivation for IT-cooperatives creating}

In the process of analyzing the motivation of IT-cooperative creating, we learned that every IT specialist (S) constantly faces the choice of one of the three areas for self-realization: 1) to work as an employee (E) for the owner of a company; 2) to work as a freelancer (F); 3) to start a company and become a business owner (B) (Fig. 1)

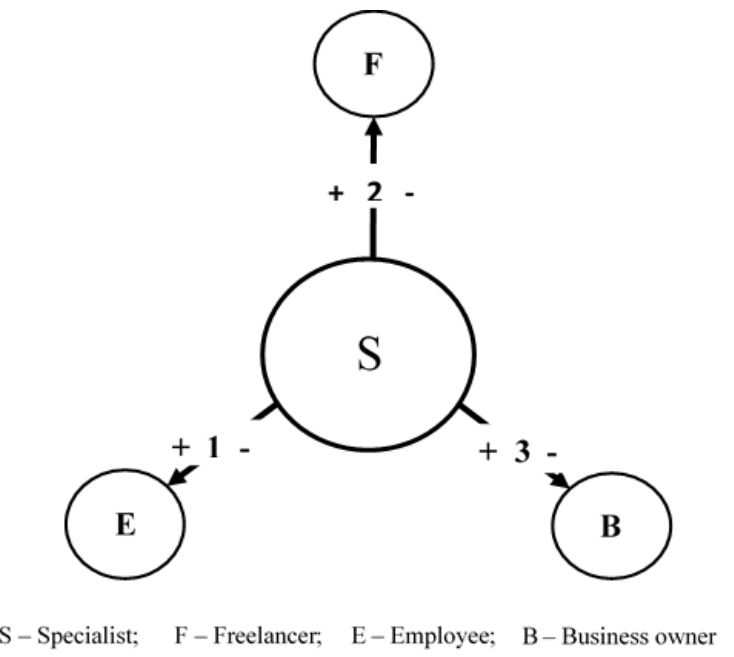

Figure 1. Possible areas of self-realization for an IT-specialist

Each of these options has its own advantages and disadvantages to remember when making decision. The main factors of motivation, identified during the research, are shown in Tables 4-6. 
Table 4. The main advantages and disadvantages of working in a company

\begin{tabular}{ll}
\hline \multicolumn{1}{c}{ Advantages $(+)$} & \multicolumn{1}{c}{ Disadvantages (-) } \\
\hline Stable salary and social package & Salary often does not correspond to the amount of work \\
Possibility of career growth & Control and intensity of work \\
Guaranteed working conditions & Daily work in the office \\
Team working & Inability to choose the type of work (projects) \\
Fixed working day & \\
\hline
\end{tabular}

Table 5. The main advantages and disadvantages of IT freelance

\begin{tabular}{ll}
\hline \multicolumn{1}{c}{ Advantages (+) } & \multicolumn{1}{c}{ Disadvantages (-) } \\
\hline Independent determination of fee & Search of orders and revenue instability \\
Self-controlled work at home & Working solo, abcence of team \\
Ability to choose the type of work (projects) & The complexity of communication with clients \\
Possibility of work in distributed team & Self-organization complexity \\
& The risks of non-payment \\
\hline
\end{tabular}

Table 6. The main advantages and disadvantages of starting an IT company

\begin{tabular}{ll}
\hline \multicolumn{1}{c}{ Advantages (+) } & \multicolumn{1}{c}{ Disadvantages (-) } \\
\hline Possibility of high current income & The need for start-up capital \\
Possibility of market identification (brand) & The need for special business skills \\
Possibility to capitalize the company and sell it & The need for a high level of professional knowledge and \\
& skills \\
& Recruitment risks \\
& Other types of business risks \\
\hline
\end{tabular}

When creating workers' cooperatives, IT professionals benefit and at the same time avoid many disadvantages which they usually have as hired employees or business owners. In a cooperative, they are simultaneously the employees and equal co-owners of their cooperative business. As the circumstances require, they additionally can work as freelancers (Fig. 2).

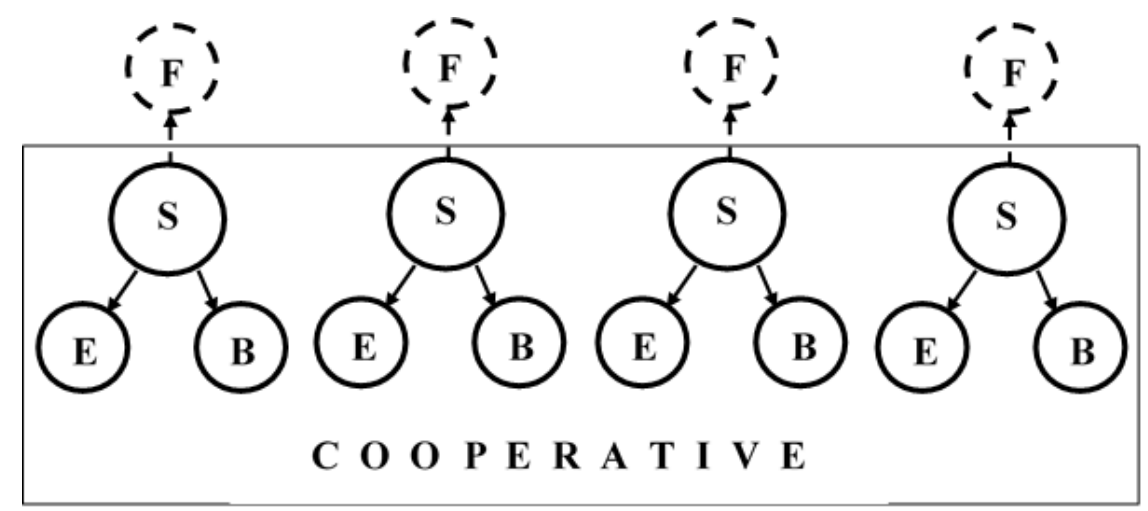

S - Specialist; E-Employee; B - Business owner; F - Freelancer

Figure 2. Status of IT specialists in their workers cooperative

\subsection{Scientific hypothesis as for different IT-cooperative models existence possibility}

The above mentioned analysis of primary information taken from websites of IT-cooperatives from different countries allowed us to conclude that the majority of such cooperatives were created as workers' ones. We did 
not find the confirmation of the other cooperative models existence in IT sector. But it does not mean that they cannot exist. Historical, logical and analogical methods allow us to formulate scientific hypothesis as for the possibility of different cooperative models in IT sector. The cooperative movement history itself may be one of the proofs of this hypothesis; it shows that the joint labor activity is the simplest form of cooperation. All the diversity of cooperatives types existing today arose due to several first social experiments on collaborative work. The idea of common purchasing of goods appeared on that basis. And then the new and more complex types and forms of cooperatives began to appear. Cooperative, as a form of mutual help, is flexible enough and can be adapted to almost all existing needs. It all depends on the needs and readiness of a society. National legislation can become the only constraining factor and that only for some period of time. The experience of international cooperative movement shows that legislation is always changing under the influence of successful practice. Fig. 3 shows some promising cooperative models that may relate to IT sector.

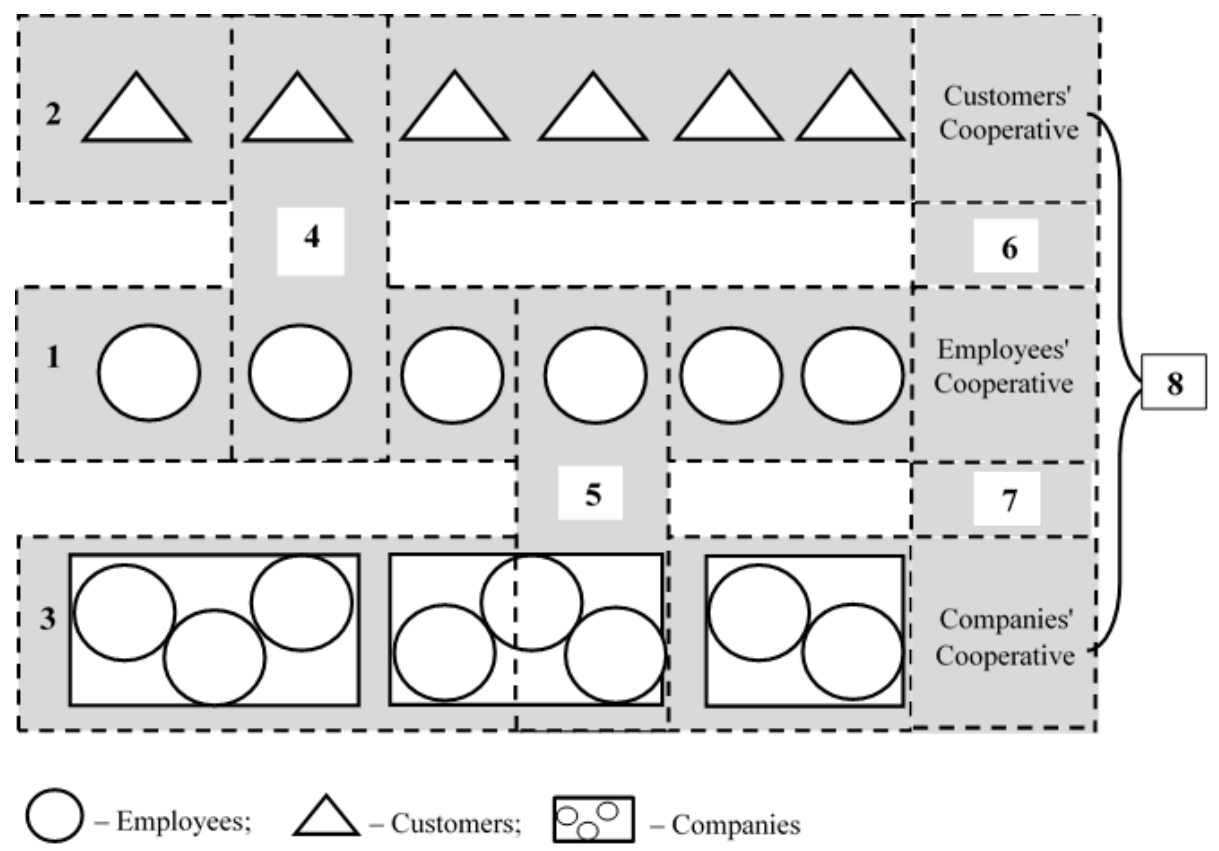

Figure 3. Possible IT-Cooperatives' models

Model 1. Cooperative uniting workers (IT specialists)

Model 2. Cooperative uniting consumers of IT services

Model 3. Cooperative uniting IT companies

Model 4. Cooperative uniting workers (IT specialists) and consumers of IT services

Model 5. Cooperative uniting workers (IT specialists) and IT companies

Model 6. Cooperative uniting consumer cooperative and workers' cooperative

Model 7. Cooperative uniting IT companies' cooperatives and workers' (IT specialists') cooperatives

Model 8. Cooperative uniting IT companies' cooperatives and cooperatives of IT services consumers

Model 9. (not presented at Fig. 3) Cooperative uniting other workers' (IT specialists) cooperatives.

The detailed description of these theoretical models is not the subject of this article. We have formulated scientific hypothesis and propose it for a broad scientific discussion.

\section{Conclusions}

In the result of our research we found out that IT-cooperative is a new, promising, but not well-known type of coop among both IT specialists and scientists. Cooperative is a unique form of business based on solidarity and ethical principles. This uniqueness is formed by the basic principles of cooperative activity. According to the results of our research, we suggested new authorial definition of the term cooperative and its classification 
into 2 groups: customers' cooperatives and workers' cooperatives. These groups have fundamental differences due to the motivation of cooperative members. The analysis of raw data from IT-cooperatives' websites in different countries showed that $97 \%$ of them could be classified as workers' cooperatives. It was also found out that IT-cooperatives provide a very wide range of services. Experience of IT-cooperatives' activity in different countries was generalized. Cooperative business model advantages for the people related to IT sector were substantiated. In this regard, we have formulated scientific hypothesis as for the possibility of different cooperative models in IT sector. We have developed nine possible perspective models of IT-cooperatives. There is not information about existence of such models yet, but they can be created in IT sector. In opinion of the authors, it makes sense to start a scientific discussion involving practicing experts in order to promote creation of IT-cooperatives. It will allow to elaborate optimal mechanisms to solve some organizational problems of IT sector representatives, especially those from small business.

\section{Abbreviations}

$\begin{aligned} \text { FAO } & \begin{array}{l}\text { Food and Agriculture } \\ \text { Organization }\end{array} \\ \text { GDP } & \text { Gross domestic product } \\ I C A & \begin{array}{l}\text { International Co-operative } \\ \text { Alliance }\end{array} \\ I L O & \begin{array}{l}\text { International Labour } \\ \text { Organization }\end{array} \\ \text { GDP } & \text { Gross Domestic Product }\end{aligned}$

\author{
POS software Point of Sale Software \\ SEO Search engine optimization \\ $U K$ the United Kingdom \\ UN United Nations \\ UNESCO United Nations Educational, Scientific \\ and Cultural Organization
}

\section{References}

[1] Babenko V.; Chebanova N.; Ryzhikova N.; Rudenko S.; Birchenko N. (2018). Research into the process of multi-level management of enterprise production activities with taking risks into consideration. EasternEuropean Journal of Enterprise Technologies, vol. 1, \# 3 (91): 4-12. (9 pages)

[2] Babenko V.; Nazarenko O.; Nazarenko I.; Mandych O. (2018). Aspects of program control over technological innovations with consideration of risks. Eastern-European Journal of Enterprise Technologies, vol. 3/4 (93): 6-14. (9 pages)

[3] Burdin G.; Dean A. (2009). New evidence on wages and employment in worker cooperatives compared with capitalist firms. Journal of Comparative Economics, 37(4): 517-533 (17 pages)

[4] Chaddad F. (2012). Advancing the theory of the cooperative organization: the cooperative as a true hybrid. Annals of Public and Cooperative Economics, 83 (4): 445-461 (17 pages)

[5] Chloupková J. (2002). European Cooperative Movement - Background and common denominators. The Royal Veterinary and Agricultural University (44 pages)

[6] Cook M.L.; Chaddad F.R.; Iliopoulos C. (2004). Advances in cooperative theory since 1990: A review of agricultural economics literature. Erasmus University Rotterdam, Rotterdam School of Management (28 pages)

[7] Co-operatives (Developing Countries) Recommendation. (1966). International Labour Organization. (https://www.ilo.org/dyn/normlex/es/f?p=NORMLEXPUB:55:0::NO::P55_TYPE,P55_LANG, P55_DOCUMENT,P55_NODE:REC,en,R127,/Document)

[8] Dave Grace \& Associates. (2014). Measuring the Size and Scope of the Cooperative Economy: Results of the 2014. Global Census on Co-operatives. United Nation's Secretariat Department of Economic and Social Affairs Division for Social Policy and Development. (https://www.un.org/esa/socdev/documents/2014/coopsegm/grace.pdf)

[9] Fratu O.; Andronache M.; Dragulinescu A.; Voicu C.; Vulpe A. (2019). Cooperation scenarios in multiagent water monitoring platform. Periodicals of engineering and natural sciences, 7(1): 261-266. (6 pages) (http://pen.ius.edu.ba/index.php/pen/article/view/393) 
[10] Goncharenko V.V. (1998). Credit Co-operation. Forms of economic self-help of rural and urban population in the world and in Ukraine (ukr.) (330 pages)

[11] Goncharenko V.; Klymko O.; Pozhar A. (2010). International principles of credit cooperative organizations' activity. Bulletin of Donetsk National University of Economics and Trade (ukr.), 4(48): 230-234. (5 pages)

[12] Goncharenko V. (2011). International co-operative principles and uniqueness of cooperatives as a form of management. Scientific works of the Poltava State Agrarian Academy. (ukr.) (http://dspace.uccu.org.ua/bitstream/123456789/3302/1/2011-Gonch-1.pdf)

[13] Goncharenko V. (2012). The importance of the revival of cooperative banks of Ukraine in terms of deepening of crisis phenomena in world economy. The International cooperative movement: genesis and modern development trends: International scientific-practical conference: 208 (1 page)

[14] Goncharenko V. (2016). International co-operative principles and development of pseudo-credit unions in Ukraine. Poltava University of Economics and Trade, Ukraine. (ukr.) (http://194.44.39.210/bitstream/123456789/5199/1/goncharenko.htm.pdf)

[15] ICA. (1995). (www.ica.coop/members/member-stats.html)

[16] ICA. (2017). Facts and figures. The International Co-operative Alliance. (https://www.ica.coop/en/cooperatives/facts-and-figures)

[17] ICA. (2018). Exploring the cooperative economy. International Cooperative Alliance. (https://monitor.coop/en)

[18] Iliopoulos C. (2003). Vertical integration, contracts, and the theory of the cooperative organization. Conference Paper, Vertical Markets and Cooperative Hierarchies: The Role of Cooperatives in the International Agri-Food Industry: 12-16. (6 pages)

[19] IT Ukraine Association; BRDO (2018). Розвиток української IT-іднустрії. Аналітичний звіт. (https://drive.google.com/file/d/1NqPqGFKpAayJuCR8emJPKTyZHm D0bPuF/view)

[20] Lima J.C. (2004). Self-manageable work in production cooperatives: the revisited paradigm. Rev. bras. Ci. Soc., 19(56): 45-62. (18 pages)

[21] Majee W.; Hoyt A. (2009). Building community trust through cooperatives: A case study of a workerowned homecare cooperative. Journal of Community Practice, 17(4): 444-463. (20 pages)

[22] Meulen R.; Bamiduro W. (2018). Gartner Says Global IT Spending to Grow 6.2 Percent in 2018. Gartner. (https://www.gartner.com/newsroom/id/3871063)

[23] Panteleimonenko A. (2008). Agrarian cooperation in Ukraine: theory and practice (ukr.). (347 pages)

[24] Pozhar A. (2013). Credit-cooperative sector of European countries' economy (ukr.). (270 pages)

[25] Promotion of Cooperatives Recommendation. (2002). International Labour Organization. (https://www.ilo.org/dyn/normlex/en/f?p=NORMLEXPUB:12100:0::NO::P12100_ILO_CO DE:R193)

[26] Quarter J.; Mook L.; Richmond B.J. (2003). What is the social economy? Centre for Urban and Community Studies, 13 (5 pages)

[27] Sapovadia V.; Patel A. (2013). What Works for Workers' Cooperatives? An Empirical Research on Success \& Failure of Indian Workers' Cooperatives. ILO Workshop, Geneva, 1(1) (30 pages)

[28] Sengupta P.; Sinha M.; Dutta U. (2019). Economic and environmental performances in manufacturing industries: A comparative study. Periodicals of engineering and natural sciences, 7(1): 99-108. (10 pages) (http://pen.ius.edu.ba/index.php/pen/article/view/416)

[29] Smith D.J.; Cargill T.F.; Meyer R.A. (1981). Credit unions: An economic theory of a credit union. The Journal of Finance, 36 (2): 519-528. (10 pages)

[30] Tech Co-op Network. (https://www.techworker.coop/members)

[31] UNESCO; ICH. (2016). Idea and practice of organizing shared interests in cooperatives. (https://ich.unesco.org/en/RL/idea-and-practice-of-organizing-shared-interests-in-cooperatives-01200)

[32] Williams R.C. (2007). The Cooperative Movement. Globalization from Below (252 pages) 